\title{
Obituary: H. B. Acton
}

By the death of Professor H. B. Acton on 16 June 1974 the Royal Institute of Philosophy has lost one of its most distinguished members and one of its most devoted servants. He was Editor of Philosophy from 1956 to 1972 and Director of the Institute from 1962 to 1964 . He served on the Council and the Executive Committee from 1947 until his death. He pursued the objects of the Institute with the judgment, energy, loyalty and learning that he also brought to his duties as Lecturer in Philosophy at University College, Swansea, Professor of Philosophy at Bedford College, University of London, and Professor of Moral Philosophy in the University of Edinburgh, as well as to his wider services to the world of philosophy and letters.

In one of his latest writings, The Idea of a Spiritual Power, the Auguste Comte Memorial Trust Lecture for 1973, he gave eloquent and dignified expression to the principles that had informed his life and his work. In recent years he had declared with increasing emphasis his concern that philosophers and other members of the academic and learned professions should retain or resume some of the responsibilities that their predecessors had exercised as the ordained clergy of an established Church. He did not share many of the other aspirations of Comte or Bentham or Mill, and he contributed in The Illusion of the Epoch one of the most cogent correctives to some of the excesses of Marx: but he did share with all these thinkers a recognition that thought has to do with action as well as with theory, and that the duties of the philosopher overlap with the duties of the citizen.

To Mrs Acton, who herself contributed generously to the work of the Institute during her years in London, goes the sympathy of all who know her and of all who knew her husband.

On Professor Acton's retirement from the editorship of Philosophy in 1972 the Council of the Royal Institute of Philosophy established in his honour, and in recognition of his services to the Institute and its journal, the $\mathbf{H}$. B. Acton Lectureship. He will be less formally but no less gratefully celebrated in the memories and affections of all who had the privilege of working with him. 